\title{
Floristic Assessment of the Mt. Bandila-an Forest Reserve in Siquijor, Philippines
}

\section{Wilbert A. Aureo ( $\nabla$ wilbert.aureo@bisu.edu.ph )}

Bohol Island State University https://orcid.org/0000-0001-7857-079X

\section{Tomas D. Reyes}

University of the Philippine Los Banos

\section{Reizl P. Jose}

Bohol Island State University

\section{Research Article}

Keywords: Central Visayas, plant assessment, Mt. Bandila-an, Siquijor Island, species diversity

Posted Date: September 1st, 2021

DOI: https://doi.org/10.21203/rs.3.rs-863087/v1

License: (1) This work is licensed under a Creative Commons Attribution 4.0 International License. Read Full License 


\author{
Wilbert A. Aureo ${ }^{* 1,3}$, Tomas D. Reyes Jr. ${ }^{2}$, and Reizl P. Jose ${ }^{1,3}$ \\ ${ }^{1}$ Department of Forestry and Environmental Sciences, College of Agriculture and \\ Natural Resources, Bohol Island State University, Bohol, Philippines 6317 \\ ${ }^{2}$ Institute of Renewable Natural Resources, College of Forestry and Natural \\ Resources, University of the Philippines Los Baños, Laguna, Philippines 4031 \\ ${ }^{3}$ Central Visayas Biodiversity Program, Office of Research and Development, \\ Bohol Island State University, Bohol, Philippines 6317 \\ *Corresponding Author: wilbert.aureo@bisu.edu.ph
}

\begin{abstract}
Mt. Bandila-an Forest Reserve is among the remaining areas with patches of closed forests in Siquijor. This forest reserve is one of the potential key biodiversity areas in Central Visayas, yet the vegetation is not fully documented. This study was conducted to specifically determine the species composition and diversity of plant species. Eight randomly distributed nested plots, each with a dimension of $20 \mathrm{~m} \mathrm{x}$ $100 \mathrm{~m}$ and subdivided to 5 equal segments of $20 \mathrm{~m} \times 20 \mathrm{~m}$, were established. A total of 188 species of plants were recorded in the plots, distributed to 131 trees, 23 shrubs, 14 vines, 11 herbs, and 9 ferns. Common plant families with more than 6 representative species were Moraceae, Rubiaceae, Fabaceae, Araceae, Euphorbiaceae, Meliaceae and Myrtaceae. There were 19 threatened (vulnerable to critically endangered) and 33 endemic species recorded in the forest reserve highlighting the importance to further conserve the area. The cluster analysis and species accumulation curve suggest that plant species are not homogeneously distributed which implies that different management and conservation strategies should be implemented across MBFR. These results not only indicate the importance of MBFR but also highlights areas with higher diversity and concentration of threatened and endemic species as a special area of concern.
\end{abstract}

Keywords: Central Visayas, plant assessment, Mt. Bandila-an, Siquijor Island, species diversity 
42

43

44

45

46

47

48

49

\section{INTRODUCTION}

The Philippines is one of 17 mega diverse countries, with more than 52,117 described species Mittermeier et al. (1997). It is highly regarded as one of the world's top biodiversity "hot spot" areas supporting 1.9 percent of the word's endemic plants and vertebrate species Myers et al. (2000). Over 57 percent of the major faunal and floral groups occur nowhere else in the world Oliver and Heaney 1996.

Central Visayas is known to have the most important karst and non-karst landscapes in the Visayas. This makes some of its ecologically important flora and fauna remarkably unique from one island to another within the region Fernando et al. (2008). Biodiversity in this part of the country is extraordinarily rich and diverse. It has 13 identified KBAs and is home to an abundance of flora and fauna found in different ecosystems. However, natural and man-made threats limit the occurrence and distribution of these precious creatures in less disturbed ecosystems. It is timely that these areas, being habitats of ecologically important and highly threatened flora and fauna, be assessed for conservation and proper management.

On the other hand, Siquijor lies off the southern coasts of Cebu, Negros and Bohol. It is part of the geopolitical West Visayas group of islands but it is not considered as part of the Negros-Panay faunal region as it is oceanic in origin Pedregosa et al. (2006); Jakosalem et al. (2005). It is located $19 \mathrm{~km}$ east of the southern tip of Negros, $30 \mathrm{~km}$ southeast of Bohol and $45 \mathrm{~km}$ north of Zamboanga peninsula at $9^{\circ} 11^{\prime} \mathrm{N}$ and $123^{\circ} 35^{\prime} \mathrm{E}$. Only four significant blocks of forest remain on the island, covering a total of 781 ha Mallari et al. (2001). All forest blocks are declared nature reserves and controlled by the Department of Environment and Natural Resources (DENR). Mt. Bandila-an Natural Park is the highest point of Siquijor at $557 \mathrm{~m}$ elevation. It is surrounded by farm lots and abandoned agricultural fields. The area contains some remnant primary lowland forest in most places, the forest is fragmented, and the undergrowth thick with saplings of large trees, shrubs and grasses Jakosalem et al. (2005). Several anthropological studies conducted in Siquijor e.g. Mascuñana et al. (1999), described folkhealing practices utilizing certain plants in the preparation of decoction Mascuñana and Mascuñan, 2008. Most of these investigators and writers emphasized the mysticism and religious aspects only.

Apparently, no extensive exploration has been done in smaller limestone islands in the Visayas like Siquijor. The results of this study will not only provide updated information on the species composition and diversity of flora in the island but will also serve as a guide for further exploration, as well as a basis for formulating and implementing guidelines for forest resources management. 
83

\section{METHODOLOGY}

\section{Study site}

The province of Siquijor is generally a hilly, coralline island, covering $344 \mathrm{~km}^{2}$ and reaching $628 \mathrm{~m}$ elevation. Mt. Bandila-an Forest Reserve (Figure 1) is among the remaining areas with patches of forest in Siquijor. It contains some remnant primary lowland forest, but is characterized by highly disturbed secondary growth dominated by fig (Ficus) tree species. In most places, the canopy is fragmented and the undergrowth thick saplings of large trees, shrubs and coarse grasses. The forests are composed into secondary area, and probably support the most important surviving population of the province endemic birds. The extant mammal fauna is largely composed of bats, including four Philippine endemic bat species. Spotted deer and Visayan warty pig are reported to have occurred in Siquijor in the past, but are almost certainly now extinct in the wild Mallari et al. (2001).
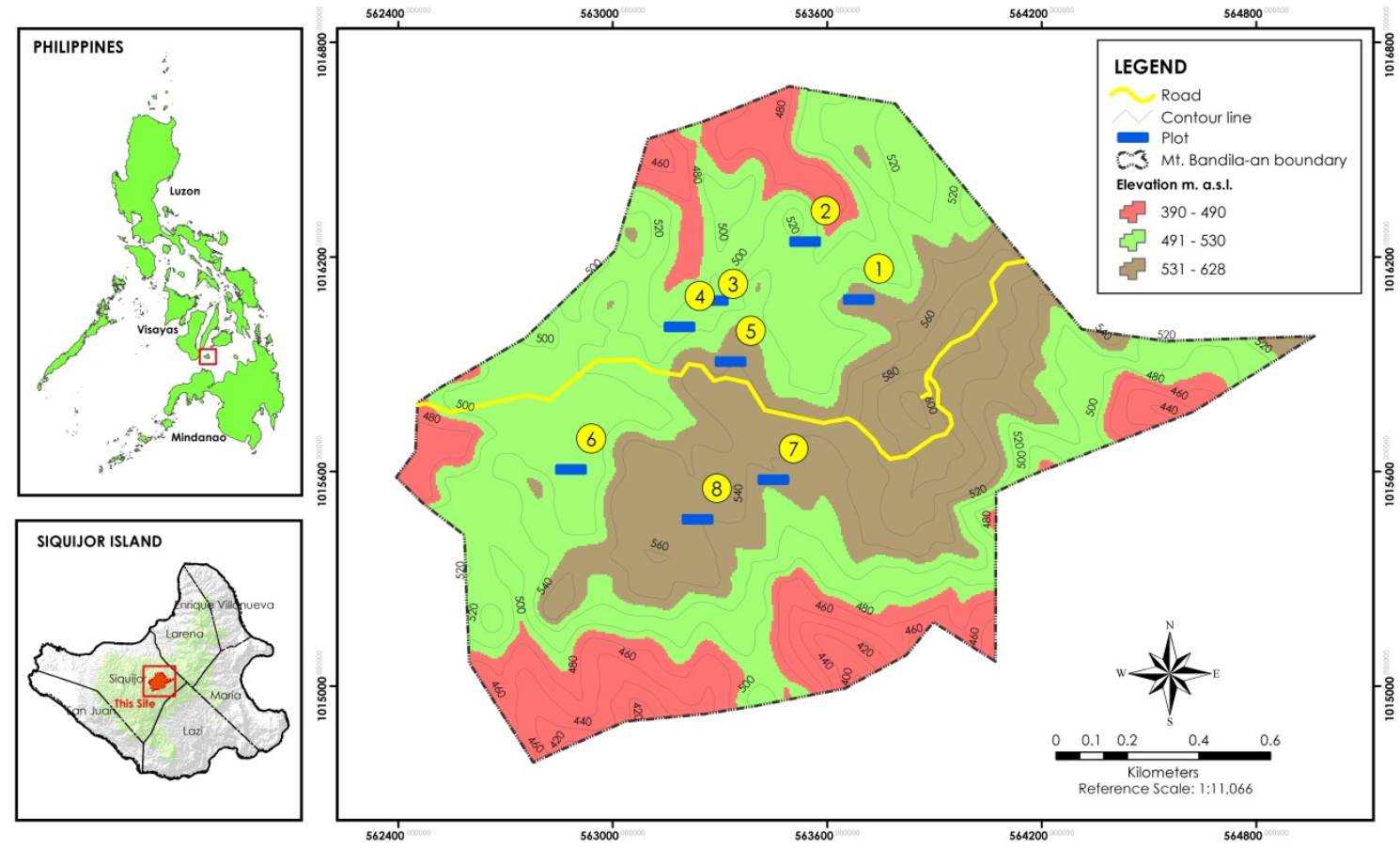

Figure 1. Topographic map of MBFR showing the locations of the sampling plots. 


\section{Field data collection}

The study was conducted from February to March 2019. Eight permanent plots, each with a dimension of $20 \mathrm{~m} \times 100 \mathrm{~m}$ were established randomly in the closed and less disturbed forested areas in Mt. Bandila-an Forest Reserve. Each sampling plot was further divided into five (5) equal segments $(20 \mathrm{~m} \times 20 \mathrm{~m})$ to facilitate recording of plants in the canopy layer having diameter at breast height $(\mathrm{DBH}, \mathrm{cm})$ of $10 \mathrm{~cm}$ and above. Nested subplot of $5 \mathrm{~m} \times 5 \mathrm{~m}$, on the other hand, was laid at the center of each segment for data recording of plants in the intermediate layer having DBH of less than $10 \mathrm{~cm}$. Further, four (4) smallest nested plots $(1 \mathrm{~m} \mathrm{x} 1 \mathrm{~m})$ on the inner edges of the $5 \mathrm{~m} \times 5 \mathrm{~m}$ plot were also laid to list down species in suppressed ground cover vegetation. Data recorded in the field were: (i) plant names from family down to species level; (ii) bio-measurements on diameter at breast height $(\mathrm{cm})$ and total height (m); (iii) plant habit of observed plants; and (iv) GPS coordinates of all corners of each segment and nested plots. For low stature plants (understorey and ground vegetation), (i) number of individuals and (ii) crown cover in percent were estimated.

\section{Plant species identification}

Identification and nomenclature were aided using the following strategies: (i) expert determination; (ii) use of flora databases (Co's Digital Flora of the Philippines; International Plant Name Index (IPNI) ), (iii) lexicons Salvosa (1963); Rojo (1999), (iv) published books (Flora Malesiana, Flora de Manila, Enumeration of Flowering Plant), field guides and other literatures e.g. de Guzman et al. (1986); Rojo and Aragones 1997; Fernando et al. (2004); Lapitan et al. (2010); Tandang et al. (2014); and Malabrigo et al. (2016); and finally (v) use of type images.

\section{Data analysis}

The relative density, relative frequency and relative dominance for each tree species in all plots were determined to obtain their importance value (IV), a standard measure in ecology that determines the rank relationships of species. High importance value of species indicates a composite score for high relative species dominance, density and frequency and provides a basis on what species can be used for restoration.

To compute for the relative density, relative dominance and relative frequency, the following formula was used Muller-Dombois and Ellenberg 1974. 
143 Density $=\frac{\text { total number of individuals of a species }}{\text { Area sampled }}$

(Equation 1)

145 Relative density $=\frac{\text { Density of a species }}{\text { Total densities of all species }} \times 100$

$146 \quad$ (Equation 2)

Dominance $=\frac{\text { Basal area (DBH area) of a species }}{\text { Total area sampled }}=\frac{\text { Crown area of a species }}{\text { Total area sampled }} \quad$ (Equation

148 3)

149 Relative dominance $=\frac{\text { Dominance of a species }}{\text { Total dominances of all species }} \times 100$

$150 \quad$ (Equation 4)

Occurence $=\frac{\text { Number of times a species is encountered }}{\text { Total number of plots established }}$

(Equation 5) Relative frequency

Furthermore, hierarchical cluster analysis (HCA) and species accumulation curve (SAC) of plots were done using Jaccard's similarity index and diversity curve respectively from Paleontological Statistics (PAST version 2.17c) Hammer and Harper 2006. The dendrogram was generated through unweighted pair-group method (UPGMA) and bootstrapping $(n=1000)$. We employed this method of analysis because it is sensitive to small samples sizes and missing observations. Diversity indices (Shannon, Simpson's and Evenness) of the sampling quadrats were computed based on the presence and absence data of all recorded species per quadrat. Index values were interpreted using the descriptions proposed by Fernando (1998) (Table 1).

Table 1. Ordinal classification of species diversity and evenness indices

\begin{tabular}{lll}
\hline Relative value rating & Species diversity $\left(\mathbf{H}^{\prime}\right)$ & Evenness $\left(\mathbf{E}^{\prime}\right)$ \\
\hline Very High & $3.50-$ above & $0.75-1.00$ \\
High & $3.00-3.49$ & $0.50-0.74$ \\
Moderate & $2.50-2.99$ & $0.25-0.49$ \\
Low & $2.00-2.49$ & $0.15-0.24$ \\
Very Low & $0.00-1.99$ & $0.05-0.14$ \\
\hline
\end{tabular}


174

175

176

177

178

179

180

181

182

183

184

185

186

187

188

189

190

191

192

193

194

195

196

197

The global and local threatened status of each species was determined from the IUCN Red List of Threatened Species 2019 using the link https://www.iucnredlist.org and from DENR DAO 2017-11 for the Philippine threatened status. Endemicity was determined through a Philippine archive of plant species Co's Digital Flora of the Philippines 2011 which is available online (https://www.philippineplants.org).

\section{RESULTS}

\section{General floristic composition}

The results of the study revealed that MBFR had recorded a total of 188 plant species belonging to 139 genera in 66 families. The dominant families of Moraceae, Rubiaceae, Fabaceae, Araceae, Euphorbiaceae, Meliaceae and Myrtaceae had more than 6 representative species (Table 2). As shown, tree species dominates with (131) species followed by the shrub (23), vine (14), herb (11) and then the fern species (9). Furthermore, genera with the highest species representation were Ficus (12) and Syzygium (6). In addition, highest number of tree species (58) was observed in plot 6 followed by plot 4 with value 51 then the lowest was plots 3 and 8 with value 42 (Figure 2). This trend was the same with shrub species, with highest number (12) in plot 6 , followed by plot 4 with 9 and lowest in plot 5 with 2 . Meanwhile, vine, herb and fern had relatively similar number of species across the plots.

Table 2. Composition of flora per plant habit in Mt. Bandila-an Forest Reserve.

\begin{tabular}{llllll}
\hline \multirow{2}{*}{ Family } & \multicolumn{2}{c}{ Plant habit } & \multicolumn{2}{c}{ Total number of } \\
\cline { 2 - 5 } species
\end{tabular}




\begin{tabular}{|c|c|c|c|c|c|c|}
\hline Calophyllaceae & & & & & 1 & 1 \\
\hline Celastraceae & & & & & 3 & 3 \\
\hline Clusiaceae & & & & & 2 & 2 \\
\hline Combretaceae & & & & & 1 & 1 \\
\hline Convolvulaceae & & & & 1 & & 1 \\
\hline Cornaceae & & & & & 1 & 1 \\
\hline Cunoniaceae & & & & & 1 & 1 \\
\hline Dipterocarpaceae & & & & & 1 & 1 \\
\hline Dryopteridaceae & 1 & & & & & 1 \\
\hline Euphorbiaceae & & & & & 8 & 8 \\
\hline Fabaceae & & & & 2 & 8 & 10 \\
\hline Fagaceae & & & & & 1 & 1 \\
\hline Hypericaceae & & & & & 2 & 2 \\
\hline Hypoxidaceae & & & 1 & & & 1 \\
\hline Lamiaceae & & 2 & & & 3 & 5 \\
\hline Lauraceae & & & & & 5 & 5 \\
\hline Leguminosae & & & & & 1 & 1 \\
\hline Lygodiaceae & 2 & & & & & 2 \\
\hline Magnoliaceae & & & & & 1 & 1 \\
\hline Malvaceae & & & & & 2 & 2 \\
\hline Maranthaceae & & 1 & & & & 1 \\
\hline Melastomataceae & & 1 & & 1 & 1 & 3 \\
\hline Meliaceae & & & & & 8 & 8 \\
\hline Menispermaceae & & & & 1 & & 1 \\
\hline Moraceae & & 3 & & & 13 & 16 \\
\hline Myristicaceae & & & & & 1 & 1 \\
\hline Myrtaceae & & & & & 8 & 8 \\
\hline Nephrolepidaceae & 1 & & & & & 1 \\
\hline Oleaceae & & & & & 1 & 1 \\
\hline Orchidaceae & & & 1 & & & 1 \\
\hline Pandanaceae & & 1 & & & & 1 \\
\hline Phyllanthaceae & & & & & 2 & 2 \\
\hline Piperaceae & & & & 1 & & 1 \\
\hline Poaceae & & & & 2 & & 2 \\
\hline
\end{tabular}




\begin{tabular}{|c|c|c|c|c|c|c|}
\hline Polypodiaceae & 1 & & & & & 1 \\
\hline Primulaceae & & 2 & & & 1 & 3 \\
\hline Proteaceae & & 1 & & & & 1 \\
\hline Rhizophoraceae & & & & & 1 & 1 \\
\hline Rosaceae & & & & & 2 & 2 \\
\hline Rubiaceae & & 6 & 1 & 1 & 6 & 14 \\
\hline Rutaceae & & & & & 4 & 4 \\
\hline Sapindaceae & & & & & 1 & 1 \\
\hline Sapotaceae & & & & & 5 & 5 \\
\hline Selaginellaceae & 3 & & & & & 3 \\
\hline Sterculiaceae & & & & & 2 & 2 \\
\hline Strombosiaceae & & & & & 1 & 1 \\
\hline Symplocaceae & & & & & 1 & 1 \\
\hline Thelypteridaceae & 1 & & & & & 1 \\
\hline Thymelaeaceae & & & & & 2 & 2 \\
\hline Urticaceae & & 1 & & & 1 & 2 \\
\hline Vitaceae & & 2 & & & & 2 \\
\hline Zingiberaceae & & & 1 & & & 1 \\
\hline Total & 9 & 23 & 11 & 14 & 131 & 188 \\
\hline
\end{tabular}




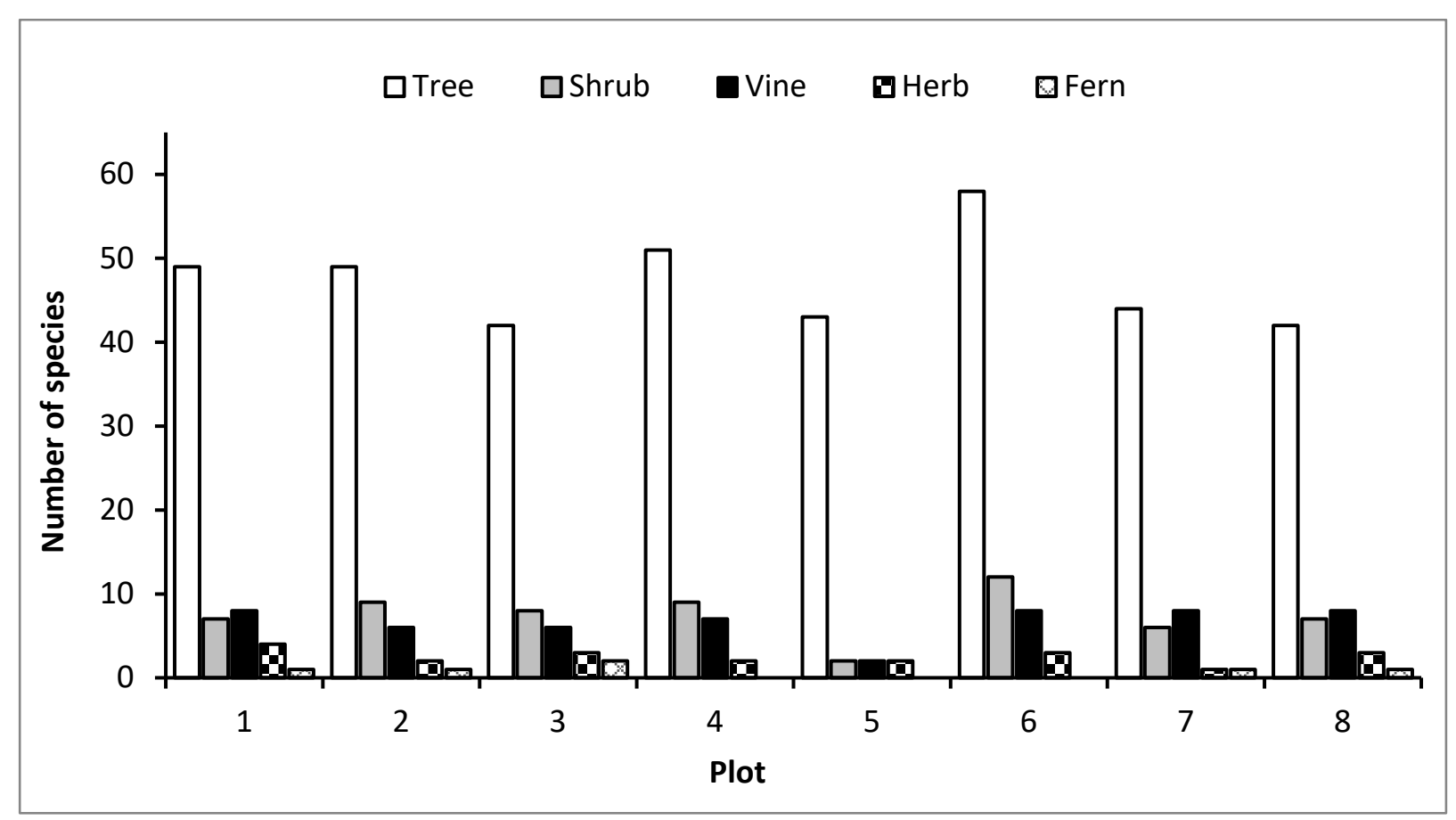

Figure 2. General plant groups of species observed per plots in MBFR

Similarity of plant species in each plot was presented in Figure 3. Three main clusters were observed. The first cluster had 2 plots (7 and 8) group together and was characterized by extreme incision, dominated by Litsea fulva. On the other hand, cluster 2 had 5 plots (2, 3, 4, 5 and 6) grouped together and was characterized by higher plant composition. This cluster was dominated by Osmoxylon eminens, Aleurites moluccanus, Calophyllum blancoi, Artocarpus nitidus, and Mangifera altissima. Lastly, plot 1 comprised cluster 3 characterized and dominated by Streblus macrophyllus. 

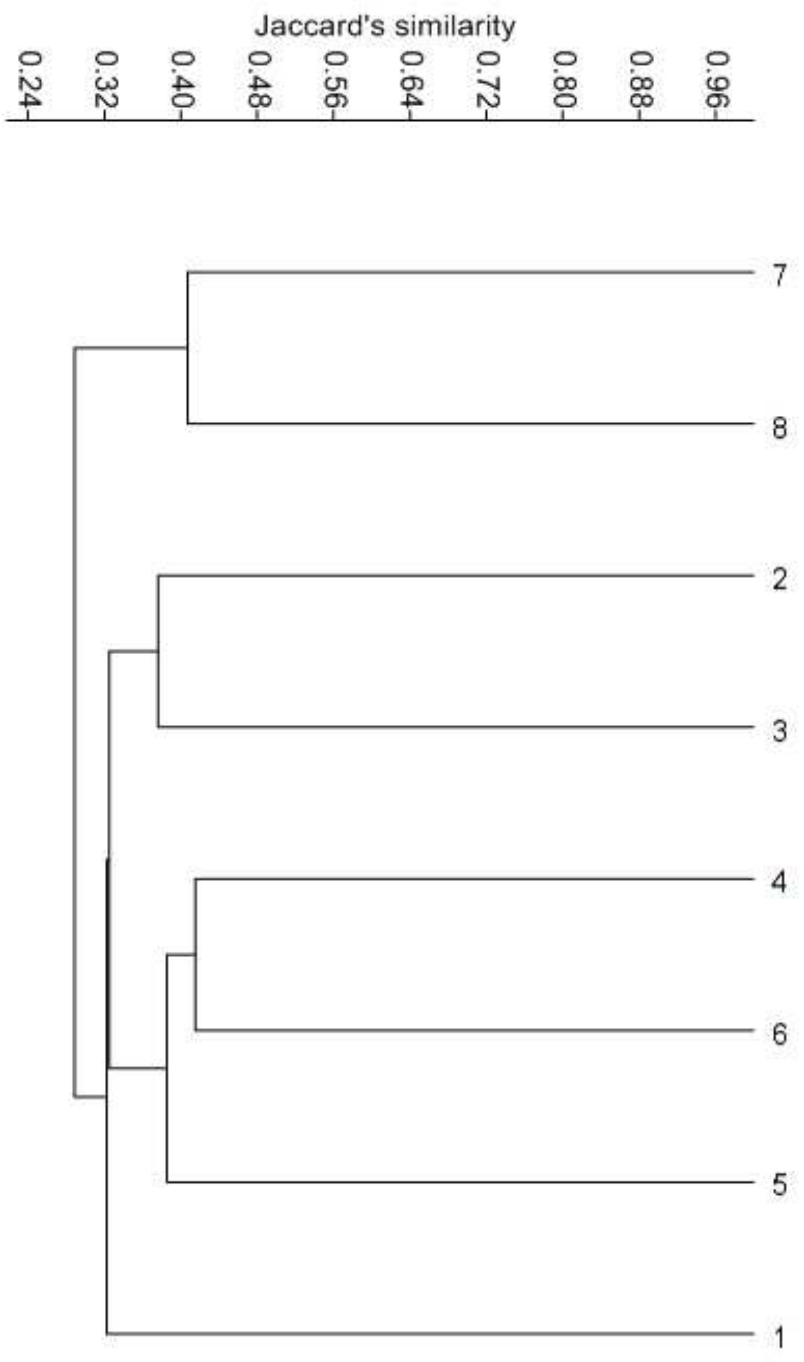

Figure 3. Dendrogram of eight sampling plots generated through UPGMA using Jaccard's Index. Bootstrapping was done at $\mathrm{n}=1000$; cophenetic correlation is 0.77 .

\section{Canopy layer}


219 The canopy layer in this study is populated by trees and other woody plants with DBH of greater than $10 \mathrm{~cm}$ recorded in $20 \mathrm{mx} 20 \mathrm{~m}$ plots. Trees of Mt. Bandila-an forest reserve is composed of 116 species with 1034 individuals. The relative density, frequency and dominance values for each tree species in all plots were determined to obtain their importance value (IV), a standard measure in ecology that determines the rank relationships of species. High importance value of species indicates a composite score for high relative species dominance, density and frequency. Based on computed importance value shown in Table 2, kubi (Artocarpus nitidus) stood as the most dominant with a value of $23.04 \%$. Large trees of Artocarpus nitidus were observed very widespread in the study site. Buhian (Litsea fulva) followed with an IV of $18.95 \%$ which also commonly observed in the site. Ipil (Intsia bijuga) with computed IV of $18.54 \%$ which was also commonly found in two of the eight plots established. Banai-banai (Radermachera quadripinnata) and balete (Ficus sp.) were also dominant in the site with computed IV of $17.12 \%, 16.98 \%$ respectively.

\section{Intermediate layer}

Intermediate layer is composed of plants (trees, shrubs, herbs, lianas) having a diameter at breast height of less than $10 \mathrm{~cm}$ but not more than $1 \mathrm{~cm}$ recorded in $5 \mathrm{~m}$ x 5m plots. A total of 79 plant species with 762 individuals were recorded in the intermediate layer of the forest in Mt Bandila-an forest reserve. The five most abundant recorded species in terms of IV were tagnos (Goniothalamus elmeri) 39.17\%, buhian (Litsea fulva) 35.09\%, malakapaya (Osmoxylon eminens) 31.77\%, os (Streblus macrophyllus) 18.24\% and ligas (Semecarpus cuneiformis) 13.64\%.

\section{Ground cover}

There are 114 ground cover species recorded from the sampled $1 \mathrm{~m} \times 1 \mathrm{~m}$ plots. It must be noted that the ground cover species referred in this survey are all species (crawling or erect) inside the plot with height of less than 1 meter. Hence, seedlings of different tree species are included as ground cover. This treatment gives us better understanding of the stand structure of the forest from the ground to the canopy. The five most dominant species that occupy the highest relative cover were bitanghol (Calophyllum blancoi) 48.14\%, buhian (Litsea fulva) 32.56, tagnos (Goniothalamus elmeri) $19.51 \%$, takipan (Caryota rumphiana) $12.77 \%$ and puso-puso (Neolitsea villosa) $10.75 \%$. (Table 3 ).

Table 3. Top 10 species with the highest importance value (IV \%) in all vegetation 257 layers.

\begin{tabular}{lll}
\hline Species & Family & IV $(\%)$ \\
\hline Canopy layer & & \\
\hline
\end{tabular}




\begin{tabular}{|c|c|c|}
\hline Artocarpus nitidus Trécul & Moraceae & 23.04 \\
\hline Litsea fulva (Blume) Fern.-Vill. & Lauraceae & 18.95 \\
\hline Intsia bijuga (Colebr.) O. Kuntze & Fabaceae & 18.54 \\
\hline Radermachera quadripinnata (Blanco) Seem. & Bignonaceae & 17.12 \\
\hline Ficus balete Merr. & Moraceae & 16.98 \\
\hline Alstonia macrophylla Wall. ex. DC. & Apocynaceae & 13.59 \\
\hline Calophyllum blancoi Planch. \& Triana & Calophyllaceae & 11.47 \\
\hline Osmoxylon eminens (W.Bull.) Philipson & Araliaceae & 11.39 \\
\hline Aleurites moluccanus (L.) Willd. & Euphorbiaceae & 10.11 \\
\hline Pterocarpus indicus Willd. & Fabaceae & 9.93 \\
\hline \multicolumn{3}{|l|}{ Intermediate } \\
\hline Goniothalamus elmeri Merr. & Annonaceae & 39.17 \\
\hline Litsea fulva (Blume) Fern.-Vill. & Lauraceae & 35.09 \\
\hline Osmoxylon eminens (W.Bull.) Philipson & Araliaceae & 31.77 \\
\hline Streblus macrophyllus Blume & Moraceae & 18.24 \\
\hline Semecarpus cuneiformis Blanco & Anacardiaceae & 13.64 \\
\hline Medinilla sp. & Melastomataceae & 12.38 \\
\hline Calophyllum blancoi Planch. \& Triana & Calophyllaceae & 11.38 \\
\hline Palaquium luzoniense (Fern.-Vill.) S.Vidal & Sapotaceae & 10.45 \\
\hline Mangifera altissima Blanco & Anacardiaceae & 8.80 \\
\hline Artocarpus nitidus Trécul & Moraceae & 7.91 \\
\hline \multicolumn{3}{|l|}{ Ground cover } \\
\hline Calophyllum blancoi Planch. \& Triana & Calophyllaceae & 48.14 \\
\hline Litsea fulva (Blume) Fern.-Vill. & Lauraceae & 32.56 \\
\hline Goniothalamus elmeri Merr. & Annonaceae & 19.51 \\
\hline Caryota rumphiana C.Mart. & Arecaceae & 12.77 \\
\hline Neolitsea villosa (Blume) Merr. & Lauraceae & 10.75 \\
\hline Streblus macrophyllus Blume & Moraceae & 10.75 \\
\hline Calamus merrillii Becc. & Arecaceae & 9.40 \\
\hline Litsea cordata (Jack) Hook.f. & Lauraceae & 8.93 \\
\hline Aglaonema philippinense Engl. & Araceae & 8.66 \\
\hline Anaxagorea luzonensis A.Gray & Annonaceae & 7.82 \\
\hline 258 & & \\
\hline 259 & & \\
\hline Tree structure and density & & \\
\hline 20, & & \\
\hline Tree density structure (Figure 4) c & ght on vertical strat & \\
\hline of the recorded trees in the area. I & lates along plots of & \\
\hline
\end{tabular}


8 (Table 4). Moreover, diameter of trees lies within $10-20 \mathrm{~cm}$ contributed about $56 \%$ and mostly recorded in plot 5 and 7 . Diameter $21-30 \mathrm{~cm}$ mostly recorded on plots 5 and 8 . The diameter class $31-40$ and $>40 \mathrm{~cm}$ has equally distributed $11 \%$ in all plots. Results revealed that large diameter trees were recorded mostly in plot 6 and 8 wherein these areas are located in steep slopes and are usually difficult to access thus, less disturbance.

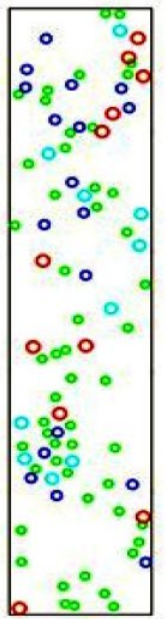

Plot 1

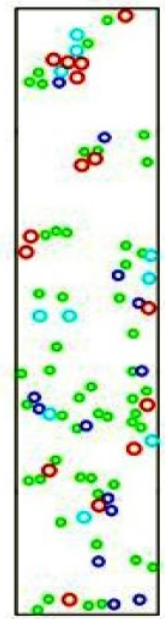

Plot 2

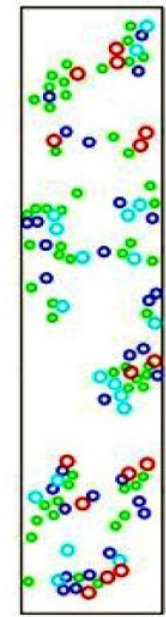

Plot 3

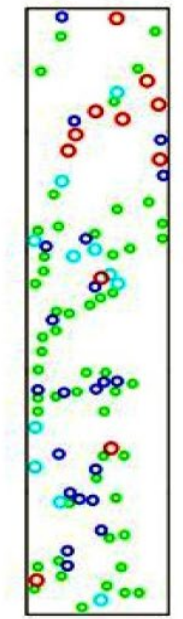

Plot 4

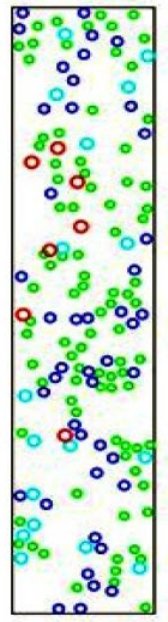

Plot 5

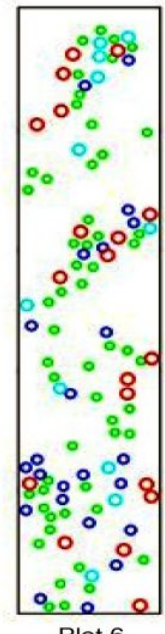

Plot 6

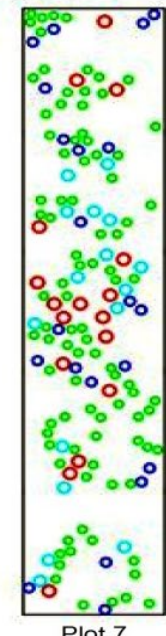

Plot 7

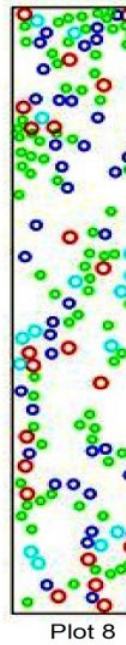

271

272

273

274

275

276

C $40 \mathrm{~cm}$ above

(-) $31-40 \mathrm{~cm}$

- $\quad 21-30 \mathrm{~cm}$

$10-20 \mathrm{~cm}$

Figure 4. Structure and density of tree species recorded in each plots of MBFR

Table 4. Diameter classes and frequency of tree species per plot in Mt. Bandila-an forest reserve.

\begin{tabular}{|c|c|c|c|c|c|c|c|c|c|c|}
\hline \multirow{2}{*}{$\begin{array}{l}\text { Diameter class } \\
(\mathrm{cm})\end{array}$} & \multicolumn{8}{|c|}{ Frequency per plot } & \multirow{2}{*}{ Total } & \multirow{2}{*}{$\%$} \\
\hline & P1 & $\mathrm{P} 2$ & $\mathrm{P} 3$ & $\mathrm{P} 4$ & P5 & P6 & P7 & P8 & & \\
\hline $10-20$ & 65 & 57 & 53 & 54 & 103 & 62 & 100 & 89 & 583 & 56 \\
\hline $21-30$ & 18 & 11 & 35 & 21 & 42 & 23 & 26 & 45 & 221 & 21 \\
\hline $31-40$ & 9 & 10 & 18 & 11 & 18 & 12 & 16 & 19 & 113 & 11 \\
\hline 40 above & 12 & 15 & 15 & 11 & 8 & 19 & 14 & 23 & 117 & 11 \\
\hline Total & 104 & 93 & 121 & 97 & 171 & 116 & 156 & 176 & 1034 & 100 \\
\hline
\end{tabular}




\section{Diversity index}

Shannon diversity index $\left(\mathrm{H}^{\prime}\right)$ gives an estimate of species richness and distribution. Plot 6 had the highest computed Shannon index $\left(H^{\prime}=3.90\right)$, followed by plot 4 with value 3.64 and lastly plot 8 with value 3.26 (Figure 5). Evenness Index tells us how evenly species and/or individuals are distributed inside a plot. Plot 6 had the highest computed evenness with value 0.61 , followed by plot 5 with value 0.58 , then lowest is plot 2 with 0.42 Simpson's Index, on the other hand, gives the probability of getting different species when two individuals were drawn (with replacement) inside a plot. Highest computed Simpson index (0.97) was in plot 6 and lowest was in plot 2 with value 0.92 . Moreover, the overall computed Shannon and Evenness indices for MBFR were 3.63 and 0.37 respectively.

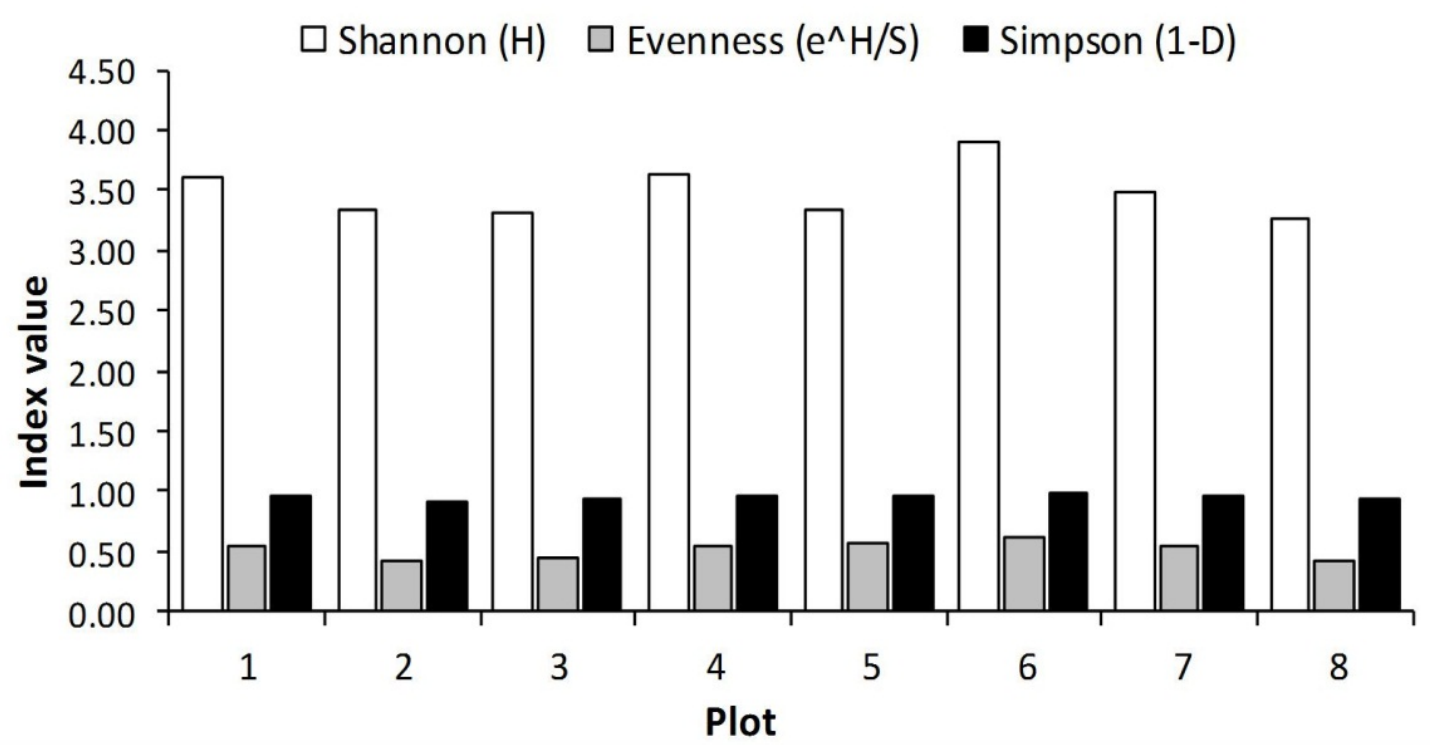

Figure 5. Plant diversity index in each plot established in MBFR.

\section{Threatened and endemic species}


299 Nineteen (19) species (Table 5) recorded from Mt. Bandila-an forest reserve are 300 listed either the Philippine Red List (DAO 2017-11) or the IUCN Red List of 301 Threatened Species (2019). Of the total 188 taxa identified to species level, 33 302 species (17.55\%) were found to be Philippine endemics or have natural habitat 303 confined only in the country.

Table 5. List of threatened species recorded in MBFR wherein; CR- critically 306 endangered, EN- endangered VU- vulnerable.

\begin{tabular}{|c|c|c|c|}
\hline Species & Family & $\begin{array}{c}\text { IUCN Red } \\
\text { List }\end{array}$ & $\begin{array}{c}\text { DENR DAO } \\
11-17 \\
\end{array}$ \\
\hline Artocarpus blancoi (Elmer) Merr & Moraceae & VU & \\
\hline Madhuca betis (Blanco) MacBride & Sapotaceae & VU & $\mathrm{EN}$ \\
\hline Dracontomelon dao (Blanco) Merr. \& Rolfe & Anacardiaceae & & VU \\
\hline Intsia bijuga (Colebr.) O. Kuntze & Fabaceae & VU & VU \\
\hline Ficus ulmifolia Lam. & Moraceae & VU & \\
\hline Toona calantas Merr. \& Rolfe & Meliaceae & & VU \\
\hline Cinnamomum mercadoi S.Vidal & Lauraceae & VU & \\
\hline Prunus grisea (Blume) Kalkm. & Rosaceae & & VU \\
\hline Meiogyne mindorensis (Merr.) Heusden & Annonaceae & & VU \\
\hline Canthium dicoccum (Gaertn.) Merr. & Rubiaceae & VU & \\
\hline Vitex parviflora Juss. & Lamiaceae & VU & EN \\
\hline Pterocarpus indicus Willd. & Fabaceae & EN & VU \\
\hline Palaquium luzoniense (Fern.-Vill.) S.Vidal & Sapotaceae & VU & $\mathrm{EN}$ \\
\hline Mangifera altissima Blanco & Anacardiaceae & VU & \\
\hline Canarium luzonicum (Blume) A.Gray & Burseraceae & VU & \\
\hline Calamus merrillii Becc. & Arecaceae & & VU \\
\hline Ardisia squamulosa Elmer & Primulaceae & VU & VU \\
\hline Macaranga grandifolia (Blanco) Merr. & Euphorbiaceae & VU & \\
\hline Shorea contorta S.Vidal & Dipterocarpaceae & CR & VU \\
\hline
\end{tabular}

\section{DISCUSSION}

The number of species recorded in this study had a cumulative total of 188 plant species in all permanent plots belonging to 139 genera in 66 families. This result was higher compared to studies conducted in forest over limestone of Dinagat island which accounted in 144 plant species belonging to 50 families and 88 genera Lillo et 
species Lillo et al. (2019) but lower compared to Canbantug forest with 192 species, 159 genera belonging to 62 plant families Replan and Malaki 2017. One of the factors that could contribute to this finding was the sampling effort and size of the forest areas, which highlights the importance of establishing sufficient number of sampling plots as suggested by the species accumulation curve (Figure 6). This is important in determining whether the plant species in the area is sufficiently represented or not. Additionaly, the result of cluster analysis exhibits heterogeneity of plant species across MBFR. This has implication on the management aspect as different vegetation structure requires specific approach. Moreover, Moraceae or figs species were the most dominant among plant families encountered across the study this is followed by coffee (Rubiaceae), legumes (Fabaceae) and herbs (Araceae) and euphorbs (Euphorbiaceae) which is in consonance with the latter studies. Fig species and Rubiaceae are known food source of bats and birds by which can lead to a high rate of seed dispersal and recolonization success Shanahan et al. (2001); Bremer and Farley 2010; Lomascolo et al. (2010). Legumes species are the majority abundant species and also been identified to play critical roles in forest restoration due to their nitrogen-fixing capability Wang et al. (2010); Chaer et al. (2011); Menge et al. (2019). Likewise, species of euphorbs also attract many pollinator species such as butterflies and birds found in the wild Simpsons (2005); Smith and Smith 2006. The open forest canopy allows light to penetrate to reach the forest floor in order to proliferate the sun-loving ground herbs and grasses which explains why legumes are found dominant in this study Durst et al. (2009). Furthermore, dominance of Araceae species indicates that forest canopy in Mt. Bandila-an is still under recovery and is actually way far from completion. Interestingly, Begoniaceae, Gesneriaceae, and other herbaceous species which are often expected on a limestone habitat were not represented in this study. Since our sampling was only done during dry season, these families of herb which are considered short-live because of its rare seeds were not observed Doorenbos et al. (1998); Bernardello (2007). 


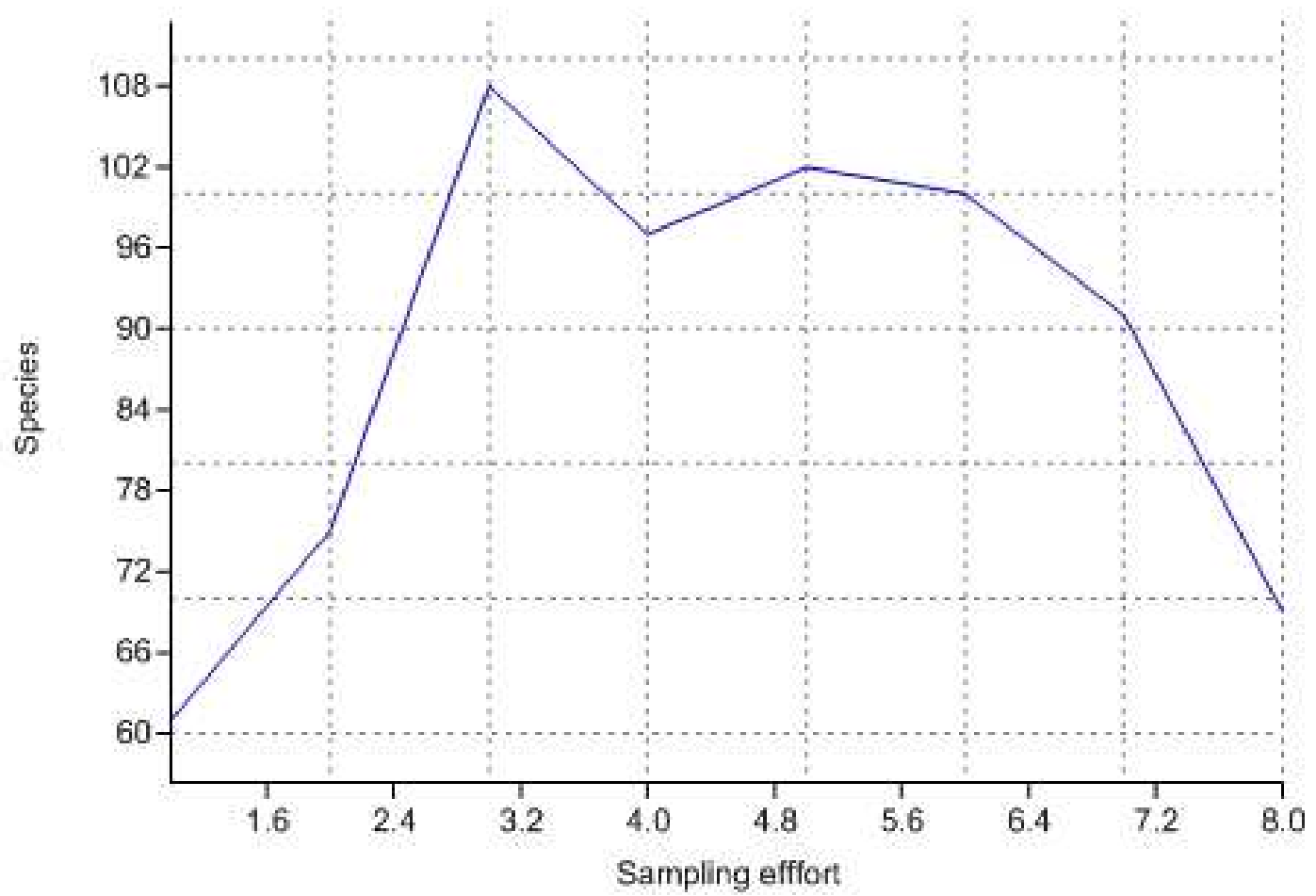

Figure 6. Species accumulation curve of plant species in each plot

All plots showed high diversity in both Shannon (H') and Simpson's (D) indices. The high diversity index for the plot is understandable considering the number of species and individuals recorded. Plot 6 had the highest Shannon index with value 3.99 while the lowest was plot 8 with value 3.26 . This high diversity could be attributed to its location where disturbance is minimal allowing the plants to regenerate faster. It is also important to note that in terms of Shannon diversity index, the ordering of the plots was mostly affected by the topography, dense forest cover and maturity of the forest Replan and Malaki 2017 where the plots were established. The high percentage value of IV of Artocarpus nitidus, Litsea fulva and Calophyllum blancoi denotes the importance of these species for future rehabilitation program. Moreover, distribution on diameter class on tree species would demonstrate different patterns on population structure and implying various different population dynamics among species Tesfaye et al. (2013). Thus, MBFR is considered a relatively young 
secondary forests characterized by smaller sized and stunted trees as evidenced by the high basal area of diameter class $(10-20 \mathrm{~cm})$.

In terms of conservation status and endemicity, 33 species were considered as Philippine endemic and 19 were threatened. This value for endemic is higher compared to the 23 recorded by Lillo et al. (2018) in Dinagat island and 19 recorded by Replan and Malaki 2017 in Canbantug forest, Cebu. In terms of threatened species, our value was higher compared to the 18 species accounted by Replan and Malaki 2017 but lower to the 25 species accounted by Lillo et al. (2018) and 30 recorded by Aureo et al. (2021) in Negros Oriental Island. Forests over limestone like MBFR have been a home for many endemic $\mathrm{c}$ and threatened species because of their unique environmental conditions, the saline soil properties, dry environment, and shallow soil parent materials, which allowed for the evolution of limestoneadapted species Querejeta et al. (2007). Presence of listed threatened and endemic species should use as reminder even on small remnant forest because they were still impact on level of biodiversity Galidon et al. (2017). The forest over limestone were considered as home for many endemic species because of their unique environmental conditions (eg., saline soil properties, dry environment and shallow soil parent materials, which allowed for the evolution of limestone adapted species Querejeta et al. (2007); Fernando et al. (2008); Liu et al. (2014) Aureo et al. (2020). Thus, appropriate management and monitoring strategies to ensure the continued survival of its population as well as other threatened species should be developed. Species confined to a particular site should be given particular conservation management strategies, as they are more vulnerable to disturbance due to their narrow range.

Exotic mahogany (Swietenia macrophylla) were planted and found growing due to seed dispersal against wind in several remnant forest of Mt. Bandila-an. This species most likely were planted due to their economic value and local practices in rehabilitating degraded areas. A total of ten individuals of mahogany with highest diameter of 76 were recorded. High number of seedlings of this species in MBFR indicates a high rate of species regeneration. According to Baguinon et al. (2003), mahogany is successful at invading natural forests due to its attributes. The number of seeds a mahogany mother tree can disperse is considerable and the seeds are recalcitrant which means it can germinate in less than a month. The seed also contains food reserves and germinate hypogeal which means that even if the initial light is relatively poor, the young mahogany plant develops even without initial photosynthesis Baguinon et al. (2003). This has implication on the future vegetation structure of MBFR as mahogany starts to invade this remaining forest.

\section{CONCLUSION}


403 Plant species assessment results implied that Mt. Bandila-an Forest Reserve has a

404 high to very high diversity and is home to at least 188 plant species. More than $17 \%$

405 of which flora are exclusively found in the country and has a significant number of 406 threatened species. It is recommended that immediate conservation and management activities should be conducted to save the threatened and endemic plant species from extirpation and control invasive exotic species. Future studies should also consider plant associations and environment interactions and should include both dry and wet seasons.

\section{ACKNOWLEDGMENTS}

The authors wish to thank Philippine Council for Agriculture, Aquatic and Natural Resources Research and Development (PCAARRD), for the financial assistance of the project. The Department of Environment and Natural Resources (DENR) PENRO-Siquijor and the Protected Area Management Board (PAMB-Siquijor) is also acknowledged for allowing and supporting the researchers in the conduct of their study. We would like to also convey deep gratefulness and heartfelt appreciation to the Central Visayas biodiversity survey team, Rochelyn Parba, Jessie Josol, Jessica Josol, Arianne Pacarat and Oscar Ido.

\section{STATEMENT ON CONFLICT OF INTEREST}

The authors do not have any conflict of interest.

\section{REFERENCES}

Aureo WA, Reyes Jr. TD, Mutia FCU, Tandang DN, Jose RP (2021) Floristic composition and community structure along the elevational gradient of Balinsasayao Twin Lakes Natural Park in Negros Oriental, Philippines. One Ecosystem 6: e56536. https://doi.org/10.3897/oneeco.5.e56536

Aureo WA, Reyes TD, Mutia FCU, Jose RP, Sarnowski MB (2020) Diversity and composition of plant species in the forest over limestone of Rajah Sikatuna Protected Landscape, Bohol, Philippines. Biodiversity Data Journal 8: e55790. https://doi.org/10.3897/BDJ.8.e55790

Baguinon, N.T., Quimado M.O., Francisco GJ. (2003). Country Report on Forest Invasive Species in the Philippines. In: McKenzie, P., Brown, C., Jianghua, S., \& Jian, W. (eds.), The Unwelcome Guests: Proceedings of the Asia-Pacific Forest 
Invasive Species Conference, FAO, Regional Office for Asia and the Pacific, Bangkok, pp. 109-160.

Bernardello, G. 2007. A systematic survey of floral nectars. In S.W. Nicolson, M. Nepi and E. Pacini (Eds) Nectares and Nectar, 19-128, Springer, Dordrecht, Netherlands

Bremer, L., \& Farley, K. (2010). Does plantation forestry restore biodiversity or create green deserts? A synthesis of the effects of land-use transitions on plant species richness. Biodiversity and Conservation 19:3893-3915

De Guzman, E.D., Umali, R.M., Sotalbo, E.D. (1986). Guide to Philippine Flora and Fauna: Dipterocarps and Non-Dipterocarps. Natural Resources Management Center. Ministry of Natural Resources and University of the Philippines. Volume 3: pp 414.

DENR Administrative Order No. 11-2017. Updated National list of Threatened Philippine Plants and their Categories. Philippine Plant Conservation Committee (PPCC) PAWB. DENR.

Doorenbos, J., Sosef, M.S.M., De Wilde, J.J.F.E. (1998). The Sections of Begonia. Wageningen Agricultural University, Netherlands

Durst, P.B., Sajise, P., Leslie, R.N. (2009). Forest beneath the grass. Proceedings of the regional workshop on advancing the assisted natural regeneration for effective low-cost restoration. Food and Agriculture Office of the United Nations Regional Office for Asia and the Pacific, Bangkok, Thailand. RAP Publication; Bohol, Philippines.

Fernando, E.S., Sun B.Y., Suh, M.H., Kong, H.Y., Koh, K.S. (2004). Flowering Plants and Ferns of Mt. Makiling. ASEAN-Korea Environmental Cooperation Unit (AKECU). National Instrumentation Center for Environmental Management, College of Agriculture and Life Sciences, Seoul National University. Pp 368.

Fernando, E.S., Co, L.S., Lagunsad, D.A., Gruezo, W., Barcelona, J.F., Madulid, D.A., Lapis A.B., Texon, G.I., Manila, A.C., Zamora, P.M. (2008). Threatened Plants of the Philippines: A preliminary assessment. The Asian International Journal Life of Science. 3: 1-52

Fernando, E.S. (1998). Forest formations and flora of the Philippines: Handout in FBS21. College of Forestry and Natural Resources, University of the Philippines Los Banos. (Unpublished). 
Galidon, J.M., Passion, B., Tongco, M.D., Fidelino, J., Duya, M.R., Ong, P. (2017). Plant diversity patterns in remnant forest and exotic tree species based reforestation in active limestone quarries in Luzon and Mindanao biogeographic sub-regions in the Philippines. Ecological Research 33.

Hammer, O., Harper, D.A. (2006). PAST. Paleontological Statistics. Version 2.07. Reference manual. Blackwell Publishing.

Jakosalem, P.G., Paguntalan, L.M., Pedregosa, M., Catacutan, M.J. (2005). Distribution and conservation importance of Volant mammals in Siquijor island in the Philippines. The Philippine Scientist. 42:159-170

Lapitan, P.G., Fernando, E.S., Suh, M.H., Fuentes, R.U., Shin, Y.K., Pampolina, N.M., Castillo, M.L., Cereno, R.P., Lee, J.H., Choi, T.B., Lee, D.K. (2010). Biodiversity and Natural Resources Conservation in Protected Areas of Korea and the Philippines. ASEAN-Korea Environmental Cooperation Unit (AKECU). National Instrumentation Center for Environmental Management, College of Agriculture and Life Sciences, Seoul National University. Pp 248.

Lillo, E., Fernando, E., Lillo, M.J. (2019). Plant diversity and forest structure of forest habitat types on Dinagat Island, Philippines. Journal of Asia-Pacific Biodiversity (12)18-105.

Lillo, E., Nuevo, R., Baltazar, A. (2019). Native trees of Mt. Lantoy Key Biodiversity Areas (KBA), Argao, Cebu, Philippines. Philippine Journal of Science. 148 (2): 365 377

Liu, J.J., Slik, J.F. (2014). Forest fragment spatial distribution matters for tropical tree conservation. Biological Conservation 171:99-106

Lomascolo, S.B, Levey, D.J., Kimball, R.T., Bolker, B.M., Alborn, H.T. (2010). Dispersers shape fruit diversity in Ficus (Moraceae). Proceedings of the National Academy of Sciences. 107(33):14668-14672

Magurran, A. (1998). Ecological diversity and its measurement. Princeton University Press, Princeton, N.J. p. 7-47.

Malabrigo, P.L. Jr., David, M., David-Pilar, M. (2016). BINHI: Tree for the Future, A Greening Legacy. Energy Development Corporation. CGKformprint, Inc. pp. 336. 
Mallari, N.A.D., Tabaranza, B.R. Jr., Crosby, M.J, Lepitan-Tabao, M., Gee, G. (2001). Key Conservation Sites in the Philippines: A Haribon Foundation and Birdlife International Directory of Important Birds. Bookmark, Makati City. Pp 486.

Mascuñana, R.V., Pioquinto, C.E., Schales, C.K. (1999). The holy week rites of the mananambal of Siquijor.Silliman Journal 40 (1): 13-47.

Mascuñana, R.V., Mascuñana, E.F. (2008). The Folk Healers: Sorcerers of Siquijor.Rex Book Store, Quezon City, 121p.

Menge, D.N.L., Chisholm, R.A., Davies, S.I., Abu Salim, K., Allen, D., Alvarez, M., America. Journal of Ecology. doi:10.5061/dryad.t1s010m

Mittermeier, R.A., Robles, G.., Mittermeier, C.G. (1997). Megadiversity. CEMEX, Mexico.

Mueller-Dombois, D., Ellenberg, H. (1974). Aims and methods of vegetation ecology. John Wiley and Sons, USA.

Myers, N., Mittermeier, R.A., Mittermeier, C.G, Da Fonseca, G.A.B, Kent, J. (2000). Biodiversity hotspots for conservation priorities. Nature 403: 853-858.

Odum, E.P. (1971). Fundamentals of Ecology. $3^{\text {rd }}$ Edition, W. B. Saunders, Philadelphia.

Oliver, W.L., Heaney, L.R. (1996). Biodiversity and conservation in the Philippines. International Zoo News 45(3):329-337.

Pedregosa, M., Paguntalan, L., Jakosalem, P., Lillo, E., Rico, E., De Alban, J.D., Lorica, R., Lastica-Ternura, E., \& Enricoso, F. (2006). An assessment of the native flora and fauna of Sicogon Island, Panay, Philippines: a consolidated report. 10.13140/RG.2.1.4720.4244.

Querejeta, J.I., Estrada-Medina, H., Allen, M.F., Jimenez-Osornio, J.J. (2007) Water source partitioning among trees growing on shallow karst soils in a seasonally dry tropical climate. Oecologia 152:26-36

Podong, C., \& Poolsiri, R. (2013). Aboveground biomass and litter productivity in relation with carbon and nitrogen content in various land use small watershed, lower 
Northern Thailand. Journal of Biodiversity and Environmental Sciences (JBES) (3): $121-132$

Replan, E.L., \& Malaki, A.B. (2017). Flora Diversity and Habitat Assessment of Cabantug Forest, Argao, Central Visayas, Cebu, Philippines. International Journal of Scientific \& Engineering Research 8:775-780

Retrieved from https://www.ipni.org Accessed on 10 November 2019

Retrieved from https://www.iucnredlist.org on 18 November 2019

Retrieved from https://www.philippineplants.org on 18 November 2019

Rojo, J.C. (1999). Revised Lexicon of Philippine Trees. Forest Products Research and Development Institute (FPRDI), Department of Science and Technology (DOST), Laguna

Rojo, J.R., Aragones, E.G. Jr. (1997). Botanical Identification Handbook on Philippine Dipterocarps. Forest Products Research and Development Institute (FPRDI)- Department of Environment and Natural Resources (DOST). Pp 97.

Salvosa, F,M. (1963). Lexicon of Philippine trees. Forest Products Research Institute. College Laguna, Philippines. Communications Media Division.

Shanahan, M., Harrison, R., Yamuna, R., Boen, W., Thornton, I. (2001). Colonization of an island volcano, Long Island, Papua New Guinea, and an emergent island, Motmot, in its caldera lake. V. Colonization by figs (Ficus spp.), their dispersers and pollinators. J Biogeogr 28:1365-1377

Simpsons, M.G. (2005). Plant Systematics, $5^{\text {th }}$ ed. New York Elsevier: Academic Press.

Smith, R.L., Smith, T,H. (1990). Ecology and Field Biology New York: Benjamin Cummings

Tandang, D.N., Tadiosa, E.R., Andes, A.P. (2014). A Pictorial Handbook on Peat Swamp Flora of Agusan Marsh, Mindanao, Philippines. Biodiversity Management 603 
604 Tesfaye, B., Hundera, K., Kelbessa, E. (2013). Floristic composition and structural 605 analysis of Jibat Humid Afromontane Forest, West Shewa Zone, Oromia National 606 Regional State, Ethiopia. Ethiop. J Educ. \& Sci. 8: 11-33. 